\title{
Leveraging asynchronous speaking tasks to promote willingness and confidence to speak in Spanish: A qualitative study
}

\author{
Nadia Jaramillo Cherrez \\ Iowa State University
}

This study describes the experiences of students in a flipped intermediate Spanish college class who used a video discussion digital tool to develop their confidence to speak in the foreign language. Students participated in a series of 10 speaking tasks designed based on the framework on technology-mediated tasks (Gonzalez-Lloret \& Ortega, 2014) and the world-readiness standards for communicative performance of the American Council on the Teaching of Foreign Languages (2015). Through semi-structured interviews and reflection journals, students shared their learning accomplishments, unveiled their inner fears in speaking skills and detailed their journey in gaining confidence to speak in Spanish. Their experiences showed that willingness to communicate and self-efficacy are driving forces that, fostered in a brave learning environment, enable students to take risks and be creative with the language. The study also presents pedagogical implications regarding the design of technology-mediated tasks and the conditions of the learning environment that can foster or hinder students' language oral communicative skills.

\section{Implications for practice or policy:}

- Technology-mediated tasks should be designed based on a learner-centred approach and the affordances of the tool to promote communicative competence in foreign and second language learning.

- Technology-mediated tasks can promote the development of confidence to use the foreign and second language more spontaneously, while allowing students to fail without being judged or penalised.

- Technology-mediated tasks can give students some control over their own learning process, facilitating opportunities for self-monitoring to gain confidence in speaking in the foreign or second language.

Keywords: technology, task-based, language learning, Spanish, communicative competence, confidence

\section{Introduction}

Although the overarching goal of learning a second language (L2) is to communicate effectively and confidently with other speakers of the L2 (Willis \& Willis, 2009; Yashima et al., 2004), spontaneous and sustained communication in that L2 is not always ensured even when learners have high linguistic competence (MacIntyre, 2007; MacIntyre et al., 1998) or available opportunities for functional uses of the L2. In addition, anxiety can negatively affect the language learning experience (C.-M. Chen \& Lee, 2011; M. R. A. Chen \& Hwang, 2020). Some students take advantage of communicative opportunities to use the L2, while others opt to avoid it (MacIntyre, 2007; MacIntyre et al., 1998). In other words, learners' willingness to communicate in the L2 depends on the context and the communication situation where the L2 is used.

A task-based approach emphasises the use of real-life tasks whereby a person uses the language for communicative purposes (Gonzalez-Lloret \& Ortega, 2014; Thomas \& Reinders, 2010). From a pedagogical standpoint, task-based instruction connects linguistic use and content, communication and interaction, language process and learners' personal experiences (Nunan, 2004). As technology has become a central element in educational settings, technology-mediated tasks can offer new opportunities for learning the L2 and for developing confidence in using it (what students can do with the language) (Gonzalez-Lloret \& Ortega, 2014; Lai \& Li, 2011; Ziegler, 2016). Research has long underscored the positive outcomes of technology-mediated tasks for language performance (Chong \& Reinders, 2020; Ziegler, 2016). However, research on the willingness to communicate and speaking confidence facilitated 
through asynchronous video tasks is under researched. In particular, research that unveils students' own stories in developing willingness and confidence in speaking is limited. Learning from students' experiences can help instructors situate themselves in their students' particular circumstances and gather in-depth understanding of their feelings and thoughts. This understanding can also guide instructors to design technology-mediated strategies with a more empathetic approach responsive to students' emotional needs.

This study investigated the experiences of college students in an intermediate flipped Spanish class. These students participated in a series of 10 asynchronous speaking tasks for developing confidence in speaking and willingness to communicate in Spanish.

\section{Willingness to communicate}

Willingness to communicate (WTC) was originally conceptualised in communication literature for first language use as the probability of engaging in communication when free to do so (McCroskey \& Baer, 1985). McCroskey and Baer viewed WTC as a personality trait with focus on speaking, which relates to communication apprehension, communicative competence, self-esteem and introversion-extroversion. WTC in the L2 is the learner's "readiness to enter into discourse at a particular time with a specific person or persons, using an L2" (MacIntyre et al., 1998, p. 547). WTC interrelates potential influences on the L2 including enduring and situational aspects. MacIntyre et al. determined that the enduring influences are stable and long-term characteristics of the context or individual. Enduring factors include motivation, affective-cognitive context and societal and individual contexts. The motivational propensity to communicate is mostly an individual difference that can be influenced by interpersonal motivation, intergroup motivation and self-confidence in the L2 (MacIntyre et al., 1998; MacIntyre \& Doucette, 2010). The first two constitute the affective and social variables of the act to communicate, while the latter involves the relationship between the speaker and the L2. Learners can feel motivated to learn an L2 and identify and affiliate with those in the L2 community (Dörnyei, 2010; Lu \& Hsu, 2008; Peng, 2012; Yashima et al., 2004), but also display attitudes of wanting to have less contact with an L2 community and be part of it.

The situational aspects can vary in a given time and can be considered more transient and dependent on context. Situational factors relate to communicative opportunities to use the L2. This includes learners' control in the use of the language, their desire to communicate with a specific person and their communicative self-confidence. MacIntyre et al. (1998) argued that "the ultimate goal of the learning process should be to engender in language students the willingness to seek out communication opportunities and the willingness to communicate in them" (p. 547), implying that opportunity alone is not sufficient condition to display WTC. According to several scholars (MacIntyre et al., 1998; MacIntyre \& Doucette, 2010; Pawlak et al., 2019), students may take the opportunity to use the L2 because presumably they feel confident in their knowledge of the language. They may also feel motivated by the context, content, perceived competence, lack of anxiety and interpersonal situation where the communication takes place. Additionally, Yashima et al. (2004) postulated that willingness to communicate is not sufficient condition to actually display communicative behavior. Other conditions, such the content of the tasks, can create L2 anxiety and possibly hinder students' willingness to speak it (C.-M. Chen \& Lee, 2011; Valadi et al., 2015). Thus, some communicative situations may involve more confidence than others, especially in relation to prior experiences in using the L2.

Yashima et al. (2004) asserted that WTC is complex and involves interrelations among several factors such as motivation to learn the L2, self-confidence in L2 communication and international posture, which influence WTC and frequency of communication in the L2. In L2 instruction, "it is hoped that the students acquire the necessary skills and WTC to change the dynamism of interaction by themselves rather than leaving it to the empathy/control of partners in intercultural interactions" (Yashima et al., 2004, p. 122). Further, Yashima et al. posited that students learning an L2 might have several goals and needs when learning the language. Therefore, individual differences related to learners' intention, readiness and confidence to use the L2 seem to influence WTC.

\section{Technology-mediated tasks}

In the context of an L2 classroom, a pedagogical task can be defined as a piece of classwork that involves "learners in comprehending, manipulating, producing, or interacting in the target language while their 
attention is focused on mobilizing their grammatical knowledge in order to express meaning, and in which the intention is to convey meaning rather to manipulate form" (Nunan, 2004, p. 4). While in the process of using the language for functional purposes, learners can build a repertoire of linguistic resources, which is presumed to induce explicit language knowledge (Ellis, 2005; Nunan, 2004; Skehan, 2003; Van den Branden, 2016) without neglecting the focus on linguistic form (Nunan, 2004; Samuda \& Bygate, 2008; Thomas \& Reinders, 2010). The use of technology-mediated tasks offers multiple advantages because these types of tasks can resemble realistic uses of the L2 that learners can encounter outside a formal learning environment (Godwin-Jones, 2011; Lai \& Li 2011; Levy \& Stockwell, 2006).

Research on technology-mediated tasks has investigated several aspects, including meaning-making with opportunities to focus on linguistic form (Hampel, 2010; Hauck \& Youngs, 2008; Rosell-Aguilar, 2005; Wang, 2014), goal orientation and intercultural awareness (Hauck \& Youngs, 2008), communication and negotiation of meaning (Smith, 2004), the development of communicative abilities (Chong \& Reinders, 2020; Kirkgöz, 2011), the achievement of a linguistic objective (Stockwell, 2010), learner centredness (Brown Nielson, 2014) and the development of linguistic content and writing processes (Oskoz \& Elola, 2016). Research on online chats, discussion platforms and gaming practices presents insights into the potential of digital technologies to promote not only language development but also to increase leaners' WTC in the L2 (Compton, 2004; Freiermuth \& Jarrell, 2006; Lepore, 2014; Reinders \& Wattana, 2014). Online chats have been found to be effective in increasing WTC, interaction (Freiermuth \& Jarrell, 2006), oral participation (Compton, 2004; Yang et al., 2012) and language performance (Chuang et al., 2018). Discussion platforms (Kissau, et al., 2010; Lepore, 2014) have been used to investigate their impact on language learning and on WTC.

\section{Asynchronous discussion tasks}

Multimodal discussion platforms have shown to promote a highly interaction environment to engage learners in real-life tasks (Kent, 2017), interactive tasks (L. Lee, 2016) and WTC. For instance, Lepore (2014) conducted a study to foster pronunciation through audio discussions in the digital tool Voice Thread. Students who participated in these discussions not only improved their French pronunciation but also their WTC as a result of their participation and the feedback they received from the instructor and their selfevaluations.

Asynchronous video discussions allow students to record videos, monitor their language performance and correct any linguistic gaps (Hirotani \& Lyddon, 2013). In these types of discussions, students can also use gestures and personalise their responses (Griffiths \& Graham, 2009) facilitating self-awareness. For example, Hirotani and Lyddon investigated Japanese and English learners' L2 self-introductions and awareness-raising through the use of asynchronous video recordings. Their L2 speaking production resembled a modified discourse structure based on each other's models of oral production. Students found the option to record video beneficial as they could self-monitor their use of language. The results suggest that asynchronous video tasks can help develop presentation and interpretive skills.

Although research shows the language benefits as well as the perceived increase in WTC, little is known from students' own account of what the experience is like while they cope with language and technologymediated tasks to build their confidence and willingness to speak more spontaneously. In view of this gap in the research, the present study examined these experiences as a crucial step to inform the design, implementation and evaluation of asynchronous speaking tasks.

\section{Methodology}

\section{Qualitative research design}

This study is part of a larger research project conducted during the first semester of 2018 at a university in the United States of America that investigated the impact of technology-mediated tasks on WTC and oral communicative performance in a flipped intermediate Spanish class. This article presents the qualitative findings investigating students' perceptions, beliefs and experiences while they participated in tasks mediated through an asynchronous video discussion platform. The study complied with the required ethical standards of the university and a research proposal was submitted prior to conducting the study. The Institutional Review Board approved the research study (IRB \#15-598 - 12/12/2017). 


\section{Participants}

The participants in this study were 28 students enrolled in a flipped fourth-year Spanish class. The majority of students identified as female $(n=21,75 \%)$. Most students had studied Spanish for more than 3 years $(n$ $=25,89 \%)$ and had not lived in a Spanish-speaking country $(n=26,93 \%)$.

\section{Development of technology-mediated tasks}

I assisted the course instructor in the design of six pedagogical tasks based on Eddy (2014) and the American Council for the Teaching of Foreign Languages (2015) world-readiness standards and performance guidelines for the interpretive and presentational communication areas. These areas emphasise individual practice and reinforce the processes of understanding, interpreting, and presenting concepts and ideas related to familiar contexts and daily life topics. The topics in the textbook were used to guide the design of the technology-mediated tasks (Table 1). The tasks required students to respond to specific speaking prompts that aimed to engage them in the practical use of spoken Spanish, utilising grammatical structures and vocabulary related to each corresponding chapter or other linguistic resources to help them accomplish the task.

Table 1

Topics in the textbook used to design the technology-mediated tasks

\begin{tabular}{lll}
\hline Flipgrid topic & Task prompts & Topic resource \\
\hline Hablemos del & Compara y contrasta un aspecto cultural entre un país de & Visual input \\
Capitulo 7 & $\begin{array}{l}\text { habla española y tu propio país [Compare and contrast one } \\
\text { cultural aspect between a Spanish-speaking country and }\end{array}$ & \\
& your own country.] & \\
\hline Hablemos del & Describe que haces para proteger el medio ambiente. & Visual and \\
Capitulo 8 & Menciona tres cosas que deberías hacer para proteger el & video input
\end{tabular}

medio ambiente pero que no las haces (lo suficiente)

[Describe what you do to protect the environment, and

mention three things you should do to protect the environment but don't do (or don't do enough).]

Hablemos del

Describe cuál crees que es el aspecto más importante

Capitulo 9 relacionado a derechos humanos/derechos civiles en los

Visual input and

Estados Unidos y en países hispano-hablantes actualmente.

Explica: ¿qué se debería hacer sobre estos aspectos.

[Describe what you think is the most important issue related

to civil rights and human rights in the United States and

Spanish-speaking countries today and explain what should be done about it. Explore the website as a resource.]

Hablemos del

Capitulo 10

Imagina que tu puedes participar en un evento histórico.

Describe cuándo tu visitarías ese evento y qué harías,

Visual and

también explica por qué este evento es importante para ti.

(Mira el video para referencia). [Imagine you could

participate in an historic event. Describe when you would

visit and what you would do, as well as why this event is important to you. (Watch the video as reference).]

\begin{tabular}{lll}
\hline Hablemos del & $\begin{array}{l}\text { Escucha la conversación en el video y responde a la } \\
\text { pregunta al final. [Watch the video and listen for the }\end{array}$ & $\begin{array}{l}\text { Input from a } \\
\text { stage } \\
\text { conversation }\end{array}$ \\
& $\begin{array}{l}\text { question at the end]. Here is the question prompt: Imagine } \\
\text { that your Spanish professor suddenly disappeared. [What do } \\
\text { you think would have happened to them and what } \\
\text { consequences would it have for you and the class?] }\end{array}$ & \\
\hline Hablemos del & $\begin{array}{l}\text { Imagina que tienes el poder para cambiar un aspecto en tu } \\
\text { vapitulo 12 }\end{array}$ & $\begin{array}{l}\text { Vida, ¿qué cambiarías y por qué? Explica tantos detalles } \\
\text { como puedas. [Imagine you have the power to change one } \\
\text { aspect in your life. What would you change and why? }\end{array}$ \\
& Explain as many details as possible.] & \\
\hline
\end{tabular}


The tasks were implemented in the video discussion platform Flipgrid. Its affordances, in particular ease of use, multimodality, personalisation, self-assessment and custom feedback, were aligned to the design of the technology-mediated oral tasks. Ease of use can engage learners in oral interactions supported by video, which enhances body language, facial expressions and paralinguistic cues. The simple intuitive navigation, use and layout can drive learners to focus on the language use rather than on troubleshooting technical problems (Liou, 2012; Zou et al., 2015), especially when the tool is new to learners. The multimodality nature of Flipgrid is more appealing to L2 instruction as it combines audio and video, offering "face time with faculty and peers ... necessary for students to feel included and integrated into the academic environment" (Allen, 2006, p. 123). The availability of Flipgrid in multiple devices facilitates the frequency of communication and interaction in the L2, an important factor in WTC and actual use of the L2. Learners can record their video postings from a computer or mobile device. Flipgrid can also allow personalisation of postings by adding titles and using emoticons and animated images to increase engagement. Finally, Flipgrid affords learners the option to self-assess and have some control over their performance prior to posting the recordings, thus, creating awareness in students of their learning process. It allows them to develop their own agency as it gives them the control over the output - an aspect that is critical for development of agency and autonomy (McLoughlin \& Lee, 2010).

\section{Data collection instruments}

The data for this study was collected in the January 2018 - May 2018 academic semester. The study used multiple means for collecting students' experiences including self-reflections, a midterm open-ended survey and focus group interviews. First, the self-reflections gathered details on how students made sense and meaning of their participation and navigation throughout the tasks and the inherent complexities of the experience (Coulson \& Harvey, 2012). The written reflections were delivered alongside the Flipgrid tasks, one per chapter, to capture students' thoughts and feelings (inward and outward looking) as well as their actions (backward and forward looking). Each reflection was individual, and the questions were related to aspects of the experience that could not be easily observed such as students' reactions, feelings, confidence level and challenges (Maxwell, 2012; Patton, 2005). The self-reflections were delivered through the Qualtrics online survey platform. Second, the midterm open-ended survey gathered students' insights from their participation in the technology-mediated tasks at a midpoint and helped adjust the tasks when possible without impacting the outcomes of the study. For example, instructions and deadlines for completion of the tasks were provided more explicitly through weekly reminders and an updated version of the schedule. Finally, the focus group interviews collected learners' overall perceptions and experiences within the socially constructed context of students' participation in the Flipgrid tasks (Merriam, 2009; Patton, 2005). A semi-structured interview protocol included questions that elicited students' reflections and considerations for communicating and participating in the technology-mediated tasks. The interview protocol had three main overarching areas of inquiry: overall understanding of the course goals, perceived speaking skills and experience within the Flipgrid tasks.

\section{Procedure}

Students completed all the technology-mediated tasks outside of class. These tasks were included in the schedule of classes but were not part of the course grade. Participation in the tasks was offered as an extra credit opportunity with specific due dates. Each task had different levels of complexity (e.g., description of familiar topics, comments on social issues, comparing information, narrate events), autonomy (e.g., impromptu speaking, evaluating progress of learning) and novelty (e.g., up-to-date topics related to social, educational or cultural issues, use the language beyond the classroom) (Eddy, 2014).

After students posted their video responses to the prompt in the Flipgrid task, they completed a written selfreflection for each task throughout the 15-week term. The midterm survey was a paper-based short questionnaire administered in the classroom in Week 8. Finally, students were invited to participate in the focus group interviews during Week 15. Two interview schedules were planned for students who agreed to participate $(n=13,46 \%)$ to conveniently select which time and day they would join the focus group interviews. The interview questions were piloted with the non-study participants to ensure the clarity of the questions. These interviews were audio-recorded. 


\section{Data analysis}

I used an iterative content analysis to examine learners' experiences during the technology-mediated speaking tasks, which included exploration, memos, coding, description and themes (Creswell, 2012). Following Saldaña's (2016) eclectic method of data analysis, a compatible set of coding methods were employed in the first and second cycles of data analysis. To analyse the task I used NVivo (v. 11.4.2). It involved initial question-based coding to gather a sense of the data, help formulate the questions in the upcoming reflections and create notes for future reference (Saldaña, 2016), followed by a second thorough reading of all data to generate phrases or concepts related to the topic of inquiry. Then, structural coding analysis was performed for the focus group interviews by segmenting the data to combine a question-based analysis to code preliminary topics and examine any similarities and differences in the segments. In this combined analysis, I coded sentence by sentence, searched for participants' actions as well as expressions of feelings and reflective thoughts and identified potential conceptual ideas that could group the codes together. Next, I coded the existing codes into more meaningful and analytical categories that exemplify the major themes and reduce any overlapping or redundant codes. The multiple sources of data used in the study helped to develop a more compressive understanding of the learners' experiences and triangulate the findings.

\section{Findings}

The findings of this qualitative study showed five major themes in students' experiences in the technologymediated tasks: (a) communicative performance opportunities, (b) language learning experience, (c) feelings and perceptions, (d) language performance barriers, and (e) experience using the Flipgrid tool. Table 2 presents a summary of the themes and description of categories.

Table 2

Five major themes and description of categories in students' experiences in the technology-mediated tasks

\begin{tabular}{|c|c|}
\hline Themes & Description of categories \\
\hline $\begin{array}{l}\text { Communicative performance } \\
\text { opportunities }\end{array}$ & $\begin{array}{l}\text { - Understanding flow of conversational style } \\
\text { - } \quad \text { Extending language practice } \\
\text { - } \quad \text { Self-monitoring }\end{array}$ \\
\hline Language learning experience & $\begin{array}{l}\text { - Practice-oriented use of language } \\
\text { - Beneficial for speaking, perspectives and boosting } \\
\text { confidence }\end{array}$ \\
\hline Feelings and perceptions & $\begin{array}{l}\text { - Satisfaction with scope of responses } \\
\text { - Confidence in oral skills and language use } \\
\text { - Maintaining focus on topic } \\
\text { - } \quad \text { Elaboration in answers } \\
\end{array}$ \\
\hline Language performance barriers & $\begin{array}{l}\text { - Unfamiliarity with content } \\
\text { - Challenges in spoken performance } \\
\text { - Anxiety and nervousness }\end{array}$ \\
\hline Experience with Flipgrid & $\begin{array}{ll} & \text { Ease of use } \\
- & \text { Flexibility } \\
- & \text { Safe environment } \\
\end{array}$ \\
\hline
\end{tabular}

\section{Communicative performance opportunities}

Students mentioned that their speaking was faster while creating responses, leading them to perceive a more spontaneous and fluent oral language production. This is illustrated by a student's comment that 'it's good to speak off command and not have much to think about your answer before you say it because it makes me feel more fluent" (Student \#1). Another student wrote, "I spoke spontaneously with a couple of notes, and I got my message across clearly" (Student \#9). The perceived immersion in a pseudo-conversational style is illustrated in the comment, "[Flipgrid task] helped me practice thinking of conversational sentences rather than responses to questions" (Student \#10). Some students also mentioned that the tasks facilitated the flow of speaking when ideas seemed to become disconnected, for example: 
[Flipgrid task] helps when you're speaking, and then you say a couple of things and then you've said enough where you can't really, change what you're going to say in Spanish and you kind of just have to figure out how to finish it. (Student \#5)

Although the technology-mediated tasks afforded the practice of spontaneous speaking, students acknowledged that at the beginning they needed to prepare notes prior to completing the tasks. However, later on the notes were no longer needed. For example, a student mentioned that at the beginning:

I wrote just small notes about things that I could talk about [in Flipgrid], but as I went on, I feel like I gained more confidence and didn't have to write those notes, and just like read the questions, and then just kind of came up with what I wanted to say and then just said that. (Student \#3)

Students perceived that the tasks allowed them the opportunity for extended practice of their speaking skills. A student commented that she felt good because she "got in some extra speaking to help in my learning" (Student \#4). In addition, a student wrote that "[Flipgrid tasks were] a good way to learn Spanish better and practice [Spanish] speaking skills more" (Student \#13). Another student shared that he developed "ways to speak about certain topics on the spot" (Student \#10). It was also mentioned that the Flipgrid tasks afforded performance monitoring since the affordances of the tool "helped to see and hear myself speak and to know what I can do better" (Student \#10). This is supported by another student, who said that "you could actually record yourself and could see a video so that you can, kind of like, correct yourself when you saw it" (Student \#7).

\section{Language learning experience}

The technology-mediated tasks furthered students' learning of Spanish by implicitly guiding the integration of the vocabulary studied in class and more complex grammar structures into their speaking. Correspondingly, their speaking confidence boosted and allowed some level of language creativity. For instance, a student said he "tried to use different tenses and vocabulary" (Student \#4), while another student shared that "I added some humor, which allowed me to play with the sentence structure" (Student \#8). Even further, a student mentioned that using grammar and vocabulary correctly along with enough details helped her "to demonstrate what I was trying to discuss" (Student \#5). Students also believed that the Flipgrid tasks served as opportunities to take risks in using uncommon and new vocabulary as well as new grammar tenses. As one student commented, "[Flipgrid tasks] helped me practice vocabulary I may have not used otherwise" (Student \#13), pushing students to breakthrough their thinking and perspectives on the topic and their current range of vocabulary, such as when the topics of human rights and politics were discussed in the tasks. In addition, students perceived a boost in their confidence in using Spanish. A student believed that he did not have to "worry about my speaking being perfect, ... I am able to relax and think, which makes my speaking more accurate" (Student \#7). The focus on using accurate use of the language was prominent in students' accounts of their experience. For example, a student shared that although he liked that he "can speak freely with no mistakes" he will try to use "better grammar" in the next Flipgrid task (Student \#6).

Students' reflections also highlighted their perceived confidence in speaking more freely. A student said that "I tried and used what I know and stuff and make mistakes, so it was nice that, like, you were just, kind of, speaking to yourself and, kind of, thinking things through in your head" (Student \#2). The extended practice that Flipgrid tasks provided seemed to have aided in students' gaining confidence to speak in Spanish, as one student pointed out, the tasks "just make you more confident because you're just getting practice" (Student \#1).

\section{Feelings and perceptions}

While completing the Flipgrid tasks, students not only had the time to reflect on their learning process, but they also became aware of their feelings. The vast majority of students shared that they felt good after completing the tasks for multiple reasons, including "It's a low-stress way of practicing Spanish" (Student \#7), "[it] allowed me enough time to complete the task" (Student \#2) and "I can answer the questions and carry out a conversation" (Student \#10). Students' reflections also showed that the feelings of satisfaction were accompanied with self-perceptions of confidence in the language abilities and instances of struggles 
with language use and accuracy. This can be illustrated by a comment from a student who shared that "I feel like my Spanish communication skills are getting better. Next time I will try and make it longer" (Student \#11). Another student reflected that, "I find it satisfying that I could discuss in depth about a topic, but I felt like I stumbled on finding the correct Spanish words many times" (Student \#3).

\section{Language performance barriers}

Students reported barriers related to their unfamiliarity with the content of some of the tasks, challenges in language accuracy and feelings of nervousness and anxiety. Several students mentioned the difficulty of elaborating answers because of their limited knowledge on more complex topics. A student commented that "it's tougher to create intellectual ideas for certain topics that I do not know that much about, or do not have enough vocabulary to give" (Student \#13). Interestingly, the findings showed some frustration due to the lack of ideas and sufficient vocabulary or because the topics were "irrelevant to everyday conversation" (Student \#5).

The results also highlight communicative barriers for language accuracy. A recurrent line of thought in students' comments showed their struggle with "talking for a longer amount of time" (Student \#11) or "without thinking of a general outline in my head first" (Student \#12). One student shared that her worries were about "[conjugating] verbs correctly spontaneously" (Student \#5), while another student kept thinking that through his participation in the Flipgrid tasks, he realised "how much I still stumble to use the right tenses" (Student \#11). In addition, a student shared that he was frustrated "because I was getting stuck a little and pronounced things slowly" (Student \#6).

\section{Experience with Flipgrid}

Several students indicated that Flipgrid was easy to use and manage, allowing them to "speak in a comfortable and relaxed environment" (Student \#10). The technology application facilitated the recording of answers multiple times allowing students to watch their videos and "be able to tell what I did right and what I need to work on more" (Student \#7). In addition, a student said that he "felt like I could just click like three buttons and [the response] would be uploaded. I mean like you could play around with it" (Student \#8). Another student commented on the convenience of using the application in a mobile device because "I didn't have to sit down and be like oh it's time, I would be like pull out my phone quick and record myself in Spanish and go along with the rest of my work" (Student \#9).

\section{Discussion}

In varying degrees, the technology-mediated tasks facilitated speaking practice environment which, according to students, was flexible, free from judgement and offered self-evaluation. This has implications for the task design, the instructional approach, the learning environment and the technology tools.

First, the findings in this study revealed high levels of students' willingness to communicate and confidence in speaking in Spanish. These perceptions are evidenced by students' reports on their increased ability, confidence and frequency to use Spanish in more spontaneously, flexibly and free from judgement. Participants' comments revealed a gradual growth in the actual speaking behavior through the continuous participation in the Flipgrid tasks, and more precisely, about their increased confidence in speaking spontaneously, the integration of more complex grammar and vocabulary in their speaking, all within a flexible and joyful environment. Students' perceptions of growth in their oral production was manifested in their account of being able to accomplish the communicative tasks. Specifically, as students pointed out, their ability to interpret and present information in a sustained oral format with enough confidence, they acknowledged their concerns about accuracy. Students initially worried about their language production lacking correct or perfect grammar.

Second, the technology-mediated tasks allowed students more frequent opportunities to develop their readiness and inclination to speak in Spanish. A plausible explanation of the increased perceptions of their WTC and increased confidence for spontaneous speaking pointed to the implementation of the technologymediated tasks facilitated by the affordances of the digital tool. These tasks offered students an opportunity to speak when they were ready to do so and steadily become more confident in the use of the language. The technology platform provided them with a space to feel safe and brave - a learning environment where 
making mistakes was normalised as a key part of the learning process instead of being penalised or judged for linguistic inaccuracies. The tool offered an out-of-classroom space to practise speaking in a joyful way where students had the opportunity to play with language and have greater engagement in their own learning process. The tool also facilitated a space where students had alternatives to rehearse and master the interpretive and presentational communicative goals (American Council for the Teaching of Foreign Languages, 2015), as well as to self-assess their own speaking performance until they were satisfied with their oral production.

Third, students' comments on the Flipgrid environment showed that their willingness to communicate and communicative performance seemed to be determined by the pressure (or lack thereof) of affective as well as linguistic factors. Because the tasks opened a space for students to post their responses asynchronously without having others seeing the posts in real-time, it appears to have lessened students' anxiety. As students themselves mentioned, there was no one to judge or criticise their speaking in real time, promoting fast thinking and speaking on-the-fly rather than perfecting their responses. This finding relates to studies that have used computer-mediated communication to enhance speaking practice, suggesting that the use of video is helpful for practising the language and that re-recording facilitates deeper learning (Lys, 2013) and promoting learning in more joyful ways (J. S. Lee \& Lee, 2020). The findings reveal how students exteriorised their feelings and thoughts of the experience; presumably perceiving themselves more confident and competent in Spanish as they steadily moved from using notes to aid their speaking to actual spontaneous speaking in the technology-mediated tasks. In addition, the digital platform Flipgrid allowed them to have some control over their speaking output, thus promoting their agency and confidence to use Spanish in more spontaneous ways.

Notwithstanding, students also reported language barriers related to the content of the tasks, language accuracy and anxiety. This finding is in line with other studies that reported connections between language performance and anxiety (C.-M. Chen \& Lee, 2011; Liu, 2012). It is clear that students' fear of being embarrassed, making mistakes and being judged in their language skills prevails as a potential barrier for communicating in Spanish. The findings might indicate that the more anxious and nervous students feel, the less likely they are to want to communicate. This anxiety decreased as students felt more comfortable and confident with speaking in a more spontaneous way, as well as altered their own approach to speaking. In addition, presumably students' unfamiliarity with the topics as a major barrier to produce language might prevent them from elaborating ideas and communicating more substantially in the target language. Students' limited knowledge on some of the topics in their own language might have also prevented them from sharing and elaborating on ideas (C.-M. Chen \& Lee, 2011).

\section{Implications for designing technology-mediated tasks}

When Gonzalez-Lloret and Ortega (2014) spoke of the integration of technology and tasks to truly respond to task-based language teaching and to the "transformative nature of new technologies" (p. 5), they had already recognised the non-neutrality of technology in learning and language use. This research study builds on the task-based learning and teaching framework by suggesting a structured and mutually informative design approach for technology-mediated tasks. This approach might serve as the place to start connecting instructional design with language teaching, technology and pedagogical tasks to maximise language learning and creativity while minimising language barriers, including fear of failure and embarrassment.

The approach to design technology-mediated tasks suggested in this study was to re-envision the design, development and evaluation of these tasks with a more student-driven experience. This suggests that teachers, educators and researchers alike need to centre the task design on students' affective as well as language needs to create a learning space that supports taking risks, being creative with the language and making mistakes as part of the learning process. This approach to task design can lead to creating activities that give students an approximation of the interactions and communications they will encounter outside the classroom (Bygate, 2016; Nunan, 2004; Van den Branden, 2016). Yet, task design should also provide learners with opportunities to focus on their own learning process not solely on the product. The technology-mediated task design approach can be realisable across language levels. It requires theoretical and practical knowledge of language learning and teaching, as well as the skills to treat technology critically. This design approach includes focal points at the intersection of learner, task and technology. 


\section{The learner, the task and the technology}

It is critical to the design of the tasks to empathise with students, especially when they are expected to communicate in speaking. Research has shown that speaking inherently brings about higher levels of anxiety for students (C.-M. Chen \& Lee, 2011; M. R. A. Chen \& Hwang, 2020); thus, a proactive action to minimise it would likely help students focus on using the language for communication. Understanding that learning a language is a context and situated process mediated by the learner can guide the design to keep the affective, language and communicative needs at the center of the task-based learning process.

Task-learner interaction refers to the nature of the language performance expected from the students. Instructors should utilise pedagogical strategies to balance the communicative nature of the tasks with systems of support for language forms (Bygate, 2016; Skehan, 2003). In designing pedagogical tasks, instructors should consider the task demands, including complexity, communicative goal, accuracy, fluency and cognitive load. As these aspects intersect at different stages of language development and performance, effective tasks will find a balance to match the learner's developmental level (Ellis, 2005). The choice of tasks will influence learners' performance and will have implications for accuracy and fluency over time (Bygate, 2016; Skehan, 2003). Therefore, in the context of the tasks with which learners interact, there needs to be an opportunity that while learners engage in meaning-centred activities and focus on form, they use the L2 in creative ways that normalise making mistakes as a critical factor in language learning instead of seeking to become a perfect speaker of the L2.

Finally, at the learner, task and technology interaction, it is important to consider how learners will access the technology, how they will likely interpret the tasks and what skills besides language they will need to address the demands of the tasks. This interaction should reflect the change that is intended for technology to offer ways to transform learning (Kenning, 2007; Laurillard, 2008) and language learning in particular with the appropriate support. In this interaction stage, learners' language level, types of tasks and technology affordances converge leading to increased but more complex opportunities for interlanguage development.

In a communicative approach, students are expected to interact and communicate with others and use the language they are learning inside and outside the classroom. Because computer-assisted language learning can focus on individual and collective work, the design of the language learning experience and the technology-mediated tasks become mutually connected. It is impossible to assume that any technologymediated task on its own will address the students' needs and that its affordances facilitate learning outcomes. The design approach used in this study encourages instructors and researchers to examine more closely the complexity of designing computer-assisted language learning experiences.

\section{Limitations and further research}

It is necessary to present some limitations that might have affected the results. First, the study was based on self-reported data from students, which might have provided a limited understanding of the entire experience in the technology-mediated tasks. Second, the data collected corresponds to students' experiences in a non-interactive set of tasks aimed to promote two aspects of the communication goal area of the American Council on the Teaching of Foreign Languages (2015) world-readiness standards: the interpretive and presentational communication standards. This might have limited the understanding of how students perceive the use of the tool to help them break the barrier of responding in a real-time interaction with a peer or Spanish-speaker interlocutor. Having students actually converse with one another in the technology-supported tasks would help draw more concrete conclusions on the impact of these tasks on their speaking production in a conversational situation.

The findings of this study warrant some directions for further research on technology-mediated pedagogical tasks. First, the study participants came from an intermediate level of Spanish and had already established a foundational understanding of the language. Having learners from lower levels of proficiency might enhance our understanding of the aspects that need further consideration in the design of tasks for beginner students. In addition, to better inform the design of tasks, it would be helpful to investigate the sequencing of the tasks and scaffolding strategies facilitated by the affordances of the technology tool (e.g., audio only, with audio and video, with other interlocutors). Finally, other factors impacting learners' willingness to communicate could be investigated to determine what motivates and what hinders their desire and intent to 
speak in the foreign or second language and that can be overcome with technology affordances (e.g., automatic feedback, peer interaction multimodality of input and output).

\section{Conclusion}

The technology-mediated pedagogical tasks not only facilitated students' growth in the willingness to communicate and communicative performance but also contributed to their increased perceived confidence to use the L2 in a spontaneous and joyful way. The video feature provided students with the option to rehearse and self-monitor their speaking, promoting learning through noticing gaps in their oral language production. Students developed confidence in spontaneous speaking and an emerging notion of the nature of a conversational style, where the importance of conveying meaning by using repair communication strategies and a repertoire of own linguistic resources prevails. The intent of the tasks was to help students develop their willingness and confidence to communicate spontaneously in diverse contexts and for multiple purposes by interpreting and presenting information as they would do in a realistic conversation. These findings can help L2 instructors design technology-mediated instruction that responds to L2 acquisition principles and language learning approaches to support the affective needs of students, especially for the speaking skill, which inherently generates higher anxiety.

\section{Acknowledgements}

The author sincerely expresses gratitude to the students and instructor in the Spanish Language Program in the World Languages Department at Iowa State University who participated in the study in 2018. The author further thanks Dr. Charlie Nagle, Director of the Spanish Language Program in the World Languages Department at Iowa State University, for encouraging the implementation of the study.

\section{References}

Allen, T. H. (2006). Is the rush to provide on-line instruction setting our students up for failure? Communication Education, 55(1), 122-126. https://doi.org/10.1080/03634520500343418

American Council on the Teaching of Foreign Languages. (2015). Performance descriptors for language learners. https://www.actfl.org/sites/default/files/publications/ACTFLPerformance Descriptors.pdf

Brown Nielson, K. (2014). Evaluation of an online, task-based Chinese course. In M. Gonzalez-Lloret \& L. Ortega (Eds.), Technology-mediated TBLT: Researching technology and tasks (pp. 295-322). John Benjamins Publishing. https://doi.org/10.1075/tblt.6.11nie

Bygate, M. (2016). Sources, developments and directions of task-based language teaching. The Language Learning Journal, 44(4), 381-400. https://doi.org/10.1080/09571736.2015.1039566

Chen, C.-M., \& Lee, T.-H. (2011). Emotion recognition and communication for reducing secondlanguage speaking anxiety in a web-based one-to-one synchronous learning environment. British Journal of Educational Technology, 42(3), 417-440. https://doi.org/10.1111/j.1467$\underline{\text { 8535.2009.01035.x }}$

Chen, M. R. A., \& Hwang, G. J. (2020). Effects of a concept mapping-based flipped learning approach on EFL students' English speaking performance, critical thinking awareness and speaking anxiety. British Journal of Educational Technology, 51(3), 817-834. https://doi.org/10.1111/bjet.12887

Chong, S. W., \& Reinders, H. (2020). Technology-mediated task-based language teaching: A qualitative research synthesis. Language Learning \& Technology, 24(3), 70-86. http://hdl.handle.net/10125/44739

Chuang, H. H., Weng, C. Y., \& Chen, C. H. (2018). Which students benefit most from a flipped classroom approach to language learning? British Journal of Educational Technology, 49(1), 56-68. https://doi.org/10.1111/bjet.12530

Compton, L. (2004). From chatting to oral fluency: Using chat to improve self-confidence and increase willingness to communicate. The Journal of Teaching English with Technology, 4(1), 1-9. https://tewtjournal.org/?wpdmact=process\&did=MTQ0LmhvdGxpbms

Coulson, D., \& Harvey, M. (2012). Scaffolding student reflection for experience-based learning: A framework. Teaching in Higher Education, 18(4), 401-413. https://doi.org/10.1080/13562517.2012.752726

Creswell, J. W. (2012). Educational research: Planning, conducting, and evaluating quantitative and qualitative research (4th ed.). Pearson. 
Dörnyei, Z. (2010). Researching motivation: From integrativeness to the ideal L2 self. In S. Hunston \& D. Oakey (Eds.), Introducing applied linguistics: Concepts and skills (1st ed., pp. 74-83). Routledge. https://doi.org/10.4324/9780203875728-17

Eddy, J. (2014). Uncovering curriculum: Language performance through culture by design. Journal of the National Council of Less Commonly Taught Languages, 17, 1-22. https://doaj.org/article/f29864ba57e2491097269c643624584e

Ellis, R. (Ed.). (2005). Planning and task performance in a second language. John Benjamins Publishing. https://doi.org/10.1075/1llt.11

Freiermuth, M., \& Jarrell, D. (2006). Willingness to communicate: Can online chat help? International Journal of Applied Linguistics, 16(2), 189-212. https://doi.org/10.1111/j.1473-4192.2006.00113.x

Godwin-Jones, R. (2011). Mobile apps for language learning. Language Learning \& Technology, 15(2), 2-11. https://doi.org/10125/44244

González-Lloret, M., \& Ortega, L. (Eds.). (2014). Technology-mediated TBLT: Researching technology and tasks. John Benjamins Publishing. https://doi.org/10.1075/tblt.6

Griffiths, M. E., \& Graham, C. R. (2009). Using asynchronous video in online classes: Results from a pilot study. International Journal of Instructional Technology and Distance Learning, 6(3), 65-76. http://itdl.org/Journal/Mar_09/article06.htm

Hampel, R. (2010). Task design for a virtual learning environment in a distance language course. In M. Thomas \& H. Reinders (Eds.), Task-based language learning and teaching with technology (pp. 131153). Continuum International Publishing. https://doi.org/ 10.5040/9781474212366.ch-007

Hauck, M., \& Youngs, B. L. (2008). Telecollaboration in multimodal environments: The impact on task design and learner interaction. Computer Assisted Language Learning, 21(2), 87-124.

https://doi.org/10.1080/09588220801943510

Hirotani, M., \& Lyddon, P. A. (2013). The development of L2 Japanese self-introductions in an asynchronous computer-mediated language exchange. Foreign Language Annals, 46(3), 469-490. https://doi.org/10.1111/flan.12044

Kenning, M. (2007). ICT and language learning: From print to the mobile phone. Palgrave Macmillan. https://doi.org/10.1057/9780230591325

Kent, D. (2017). Constructing visually-based digital conversations in EFL with Voicethread. The Journal of Teaching English with Technology, 17(1), 3-16. https://tewtjournal.org/?wpdmact=process\&did=NDgzLmhvdGxpbms

Kirkgöz, Y. (2011). A blended learning study on implementing video recorded speaking tasks in taskbased classroom instruction. Turkish Online Journal of Educational Technology, 10(4), 1-13. http://www.tojet.net/articles/v10i4/1041.pdf

Kissau, S., McCullough, H., \& Pyke, J. G. (2010). Leveling the playing field: The effects of online second language instruction on student willingness to communicate in French. CALICO Journal, 27(2), 277-297. https://doi.org/10.11139/cj.27.2.277-297

Lai, C., \& Li, G. (2011). Technology and task-based language teaching: A critical review. CALICO Journal, 28(2), 498-521. https://doi.org/10.11139/cj.28.2.498-521

Laurillard, D. (2008). Open teaching: The key to sustainable and effective open education. In T. Iiyoshi \& M. V. Kumar (Eds.), Opening up education: The collective advancement of education through open technology, open content, and open knowledge (pp. 319-335). MIT Press. http://mitp-contentserver.mit.edu:18180/books/content/sectbyfn?collid=books_pres_0\&id=7641\&fn=9780262515016 pr e 0001.pdf\#page $=341$

Lee, J. S., \& Lee, K. (2020). Affective factors, virtual intercultural experiences, and L2 willingness to communicate in in-class, out-of-class, and digital settings. Language Teaching Research, 24(6), 813833. https://doi.org/10.1177/1362168819831408

Lee, L. (2016). Autonomous learning through task-based instruction in fully online language courses. Language Learning \& Technology, 20(2), 81-97. http://llt.msu.edu/issues/june2016/lee.pdf

Lepore, C. E. (2014). Influencing students' pronunciation and willingness to communicate

through interpersonal audio discussions. Dimension, 2014, 73-96. https://www.scolt.org/wpcontent/uploads/2019/08/Dimension2014_FINAL.pdf

Levy, M., \& Stockwell, G. (2006). CALL dimensions: Options and issues in computer-assisted language learning. Lawrence Erlbaum.

Liou, H. C. (2012). The roles of Second Life in a college computer-assisted language learning (CALL) course in Taiwan, ROC. Computer Assisted Language Learning, 25(4), 365-382. https://doi.org/10.1080/09588221.2011.597766 
Liu, H. J. (2012). Understanding EFL undergraduate anxiety in relation to motivation, autonomy, and language proficiency. Electronic Journal of Foreign Language Teaching, 9(1), 123-139. https://e-flt.nus.edu.sg/wp-content/uploads/2020/09/v9n12012/liu.pdf

Lu, Y., \& Hsu, C.-F. (2008). Willingness to communicate in intercultural interactions between Chinese and Americans. Journal of Intercultural Communication Research, 37(2), 75-88. https://doi.org/10.1080/17475750802533356

Lys, F. (2013). The development of advanced learner oral proficiency using iPads. Language Learning \& Technology, 17(3), 96-116. http://1t.msu.edu/issues/october2013/lys.pdf

MacIntyre, P. D. (2007). Willingness to communicate in the second language: Understanding the decision to speak as a volitional process. Modern Language Journal, 91(4), 564-576. https://doi.org/10.1111/j.1540-4781.2007.00623.x

MacIntyre, P. D., Dornyei, Z., Clément, R., \& Noels, K. A. (1998). Conceptualizing willingness to communicate in a L2: A situational model of L2 confidence and affiliation. Modern Language Journal, 82(4), 545-562. https://doi.org/10.1111/j.1540-4781.1998.tb05543.x

MacIntyre, P. D., \& Doucette, J. (2010). Willingness to communicate and action control. System, 38(2),

161-171. https://doi.org/10.1016/j.system.2009.12.013

McCroskey, J. C., \& Baer, J. E. (1985, November 7-10). Willingness to communicate: The construct and its measurement [Paper presentation]. Annual Meeting of the Speech Communication Association, Denver, CO, United States of America.

Maxwell, J. A. (2012). Qualitative research design: An interactive approach (3rd ed.). Sage.

McLoughlin, C., \& Lee, M. J. (2010). Personalised and self-regulated learning in the Web 2.0 era: International exemplars of innovative pedagogy using social software. Australasian Journal of Educational Technology, 26(1), 28-43. https://doi.org/10.14742/ajet.1100

Merriam, S. B. (2009). Qualitative research: A guide to design and implementation. Jossey-Bass.

Nunan, D. (2004). Task-based language teaching: A comprehensively revised edition of designing tasks for the communicative classroom. Cambridge University Press. https://doi.org/10.1017/CBO9780511667336

Oskoz, A., \& Elola I. (2016). Digital stories: Overview. CALICO, 33(2), 157-173. https://doi.org/10.1558/cj.v33i2.29295

Patton, M. Q. (2005). Qualitative research. Encyclopedia of statistics in behavioral science. Sage. https://doi.org/10.1002/0470013192.bsa514

Pawlak, M., Mystkowska-Wiertelak, A., \& Bielak, J. (2016). Investigating the nature of classroom willingness to communicate (WTC): A micro-perspective. Language Teaching Research, 20(5), 654671. https://doi.org/10.1177/1362168815609615

Peng, J. E. (2012). Towards an ecological understanding of willingness to communicate in EFL classrooms in China. System, 40(2), 203-213. https://doi.org/10.1016/j.system.2012.02.002

Reinders, H., \& Wattana, S. (2014). Can I say something? The effects of digital game play on willingness to communicate. Language Learning \& Technology, 18(2), 101-123. http://llt.msu.edu/issues/june2014/reinderswattana.pdf

Rosell-Aguilar, F. (2005). Task design for audiographic conferencing: Promoting beginner oral interaction in distance language learning. Computer Assisted Language Learning, 18(5), 417-442. https://doi.org/10.1080/09588220500442772

Saldaña, J. (2016). The coding manual for qualitative researchers (3rd ed.). Sage.

Samuda, V., \& Bygate, M. (2008). Tasks in second language learning. Palgrave Macmillan. https://doi.org/10.1057/9780230596429

Skehan, P. (2003). Focus on form, tasks, and technology. Computer Assisted Language Learning, 16(5), 391-411. https://doi.org/10.1076/call.16.5.391.29489

Smith, B. (2004). Computer-mediated negotiated interaction and lexical acquisition. Studies in Second Language Acquisition, 26, 365-398. https://doi.org/10.1017/s027226310426301x

Stockwell, G. (2010). Effects of multimodality in computer-mediated communication tasks. In M. Thomas \& H. Reinders (Eds.), Task-based language learning and teaching with technology (pp. 83104). Continuum International Publishing. https://doi.org/10.5040/9781474212366.ch-005

Thomas, M., \& Reinders, H. (Eds). (2010). Task-based language learning and teaching with technology. Continuum International Publishing. https://doi.org/10.5040/9781474212366

Valadi, A., Rezaee, A., \& Baharvand, P. K. (2015). The relationship between language learners' willingness to communicate and their oral language proficiency with regard to gender differences. International Journal of Applied Linguistics and English Literature, 4(5), 147-153. https://doi.org/10.7575/aiac.ijalel.v.4n.5p.147 
Van den Branden, K. (2016). Task-based language teaching. In G. Hall (Ed.), The Routledge Handbook of English language teaching (pp. 238-251). Routledge. https://www.routledgehandbooks.com/doi/10.4324/9781315676203.ch17

Wang, A. (2014). Managing student participation: Teacher strategies in a virtual EFL course. The Journal of the JALT CALL, 10(2), 105-125. https://doi.org/10.29140/jaltcall.v10n2.170

Willis, D., \& Willis, J. (2009). Task-based learning: Some questions and answers. The Language Teacher, 33(3), 3-8. https://jalt-publications.org/sites/default/files/pdf-article/33.3 art1.pdf

Yang, Y. T. C., Gamble, J., \& Tang, S. Y. S. (2012). Voice over instant messaging as a tool for enhancing the oral proficiency and motivation of English-as-a-foreign-language learners. British Journal of Educational Technology, 43(3), 448-464. https://doi.org/10.1111/j.1467-8535.2011.01204.x

Yashima, T., Zenuk-Nishide, L., \& Shimizu, K. (2004). The influence of attitudes and affect on willingness to communicate and second language communication. Language Learning, 54(1), 119152. https://doi.org/10.1111/j.1467-9922.2004.00250.x

Ziegler, N. (2016). Taking technology to task: Technology-mediated TBLT, performance, and production. Annual Review of Applied Linguistics, 36, 136-163. https://doi.org/10.1017/S0267190516000039

Zou, B., Wang, D., \& Xing, M. (2015). Collaborative tasks in wiki-based environment in EFL learning. Computer Assisted Language Learning, 29(5), 1001-1018. https://doi.org/10.1080/09588221.2015.1121878

Corresponding author: Nadia Jaramillo Cherrez, nadia.jaramillo33@gmail.com

Copyright: Articles published in the Australasian Journal of Educational Technology (AJET) are available under Creative Commons Attribution Non-Commercial No Derivatives Licence (CC BY-NC-ND 4.0). Authors retain copyright in their work and grant AJET right of first publication under CC BY-NC-ND 4.0 .

Please cite as: Jaramillo Cherrez, N. (2022). Leveraging asynchronous speaking tasks to promote willingness and confidence to speak in Spanish: A qualitative study. Australasian Journal of Educational Technology, 38(1), 1-14. https://doi.org/10.14742/ajet.6657 